\title{
Histórias entrelaçadas: a dimensão da resistência em Vidas secas e Abril despedaçado
}

\author{
Interwoven stories: the dimension of resistance \\ in Vidas secas and Abril despedaçado \\ Maria Margarete Souza Campos COSTA* \\ Universidade Estadual de Santa Cruz (UESC) \\ Sandra Maria Pereira do SACRAMENTO** \\ Universidade Estadual de Santa Cruz (UESC)
}

\begin{abstract}
RESUMO: Esse artigo faz uma abordagem comparativa entre o romance Vidas secas (1938) de Graciliano e o filme Abril despedaçado (2001), de Walter Salles, cujo objetivo foi refletir sobre a dimensão da resistência das personagens femininas, bem como, de outras personagens, que, embora, vivendo numa condição de subjugação, e, situadas em um contexto falocêntrico, desenvolvem ao seu turno estratégias de resistência, abrem fissuras na ordem instituída e desestabilizam a hierarquia patriarcal. O referencial teórico está ancorado na teoria de Badinter; Judith Butler; Perrot; Richard; Derrida; Hutcheon; Stearns, entre outros, que se utilizam do pósestruturalismo para construir as suas formulações. Da mesma forma, buscamos a contribuição de alguns autores cujos pontos de vista versam sobre as narrativas de ficção, sejam literárias ou audiovisuais, como: Coutinho; Cunha; Johnson; Munsterberg; Neitzel; Resende e Xavier.
\end{abstract}

PALAVRAS-CHAVE: Comparatismo. Literatura. Cinema. Relações de gênero.

ABSTRACT: This article makes a comparative approach between the novel Vidas secas (1938) of Graciliano Ramos and the film Abril despedaçado (2001), by Walter Salles, whose goal was to reflect on the dimension of resistance of the female characters, as well as other characters, which although living in a state of subjugation, and situated in a phallocentric context, have developed strategies of resistance, in turn, fissures open in the established order and destabilizing the patriarchal hierarchy. The theoretical framework is grounded in theory Badinter; Judith Butler; Perrot; Richard; Derrida; Hutcheon; Stearns, among others, that use of post-structuralism to build their formulations. Likewise, we seek the contribution of some authors whose views on narratives of fiction, or literary or audiovisual works, such as: Coutinho; Cunha; Johnson; Munsterberg; Neitzel; Resende and Xavier.

KEYWORDS: Comparatism. Literature. Movie. Gender relations.

\footnotetext{
* Mestranda em Letras: Linguagens e Representações - Universidade Estadual de Santa Cruz (UESC) Ilhéus - Bahia. Email: guetecampos @ hotmail.com.

${ }^{* *}$ Doutora em Letras (Letras Vernáculas) pela Universidade Federal do Rio de Janeiro (2000). Atualmente é professora titular (plena) em Teoria Literária, na Universidade Estadual de Santa Cruz, em Ilhéus, Bahia onde coordena o programa em Letras: Linguagens e Representações, aprovado pela Capes, em 2007. Desenvolve projeto acerca da representação feminina na obra de Jorge Amado. É membro do GT Mulher e Literatura da ANPOLL, da Rede de Estudos Avançados em Leitura. - RELER, grupo ligado à Cátedra UNESCO de Leitura- PUC/Rio. Rio de Janeiro - Rio de Janeiro. Email: sandramsacra@ uesc.br.
} 


\section{Introdução}

O comparatismo tem se consolidado como tendência no campo das pesquisas literárias e interdisciplinares do século XXI. Analisar teoricamente obras literárias entre si, ou estas em relação a outras produções artísticas, numa perspectiva comparatista, permite que se tenha um olhar interdiscursivo sobre as especificidades das obras, dos métodos utilizados no processo de criação, como também, do contexto histórico e/ou cultural imbricados nessas construções. Um exemplo disso são os estudos de gênero, que em outras possibilidades de análises estão aparentemente invisíveis nas tramas da ficção. Além disso, as pesquisas realizadas nesse âmbito remetem a questões relativas às diferenças, à representação e à identidade. Configura-se assim, a pertinência do comparatismo à contemporaneidade, caracterizada por desordens e irregularidades que compõem a simultaneidade, bem como, a heterogeneidade de imagens produzidas e disseminadas no cotidiano fragmentado da pós-modernidade.

Observa-se então, que o cruzamento do comparatismo com as rupturas efetuadas no pensamento ocidental contribuiu para desestabilizar valores hegemônicos. Há possibilidades múltiplas em analisar comparativamente diferentes linguagens, entre elas, a literatura e o cinema, que consistem num desafio de aproximação e dialogismo bastante enriquecedor. Embora, esses dois tipos de expressão artística sejam produzidos, em parte, por diferentes meios. A literatura centra-se na palavra, enquanto o cinema na imagem.

Essas diferenças não se traduzem por completo, mas, dialogam a priori, por constituírem formas de narratividade, consumando-se então, em relações, tanto no que se refere aos traços estéticos quanto aos modos de produção. São muitos os aspectos que confluem para o diálogo entre essas artes, evidenciados sobremodo, pela analogia autor/diretor. Ambos voltados para a construção dos elementos que estruturam a narrativa, como espaço, tempo, personagens, quer seja literária, quer seja audiovisual. Nesse sentido, tanto a palavra quanto a imagem são produtoras de discurso narrativo, pois as duas constituem linguagens, sendo que a segunda precede à primeira. Como assegura Randal Johnson "As relações entre literatura e cinema são múltiplas e complexas caracterizadas por uma forte intertextualidade" (JOHNSON, 2003, p. 36). Através do processo narrativo, o homem elabora-se enquanto ser histórico, capaz de contar um passado, problematizar o presente e vaticinar o devir. Ainda sobre a relação cinema/literatura Everaldo Coutinho compreende que "tanto as letras quanto os painéis cinematográficos são transmissores de pensamento para quem, respectivamente, lê um livro, ou vê um filme" (COUTINHO, 1996, p. 104).

A imagem traduz-se enquanto linguagem do homem pré-histórico, que através dela registrou os modos de viver, de relacionar-se consigo mesmo e com a natureza. Assim, as pinturas rupestres nas cavernas inauguraram as narrativas visuais. $\mathrm{O}$ processo da evolução humana possibilitou ao homem depois, desenvolver símbolos para representar os diferentes sons por ele enunciados. Por conseguinte, tais signos deram origem às palavras, e estas por fim, consolidaram a expressão do pensamento humano. Desde então, as imagens mentais passaram a ser materializadas na escrita. É necessário salientar que o entrelaçamento entre imagem e palavra permite ao homem desvendar e/ou subverter os enigmas, além de permear tanto a interioridade quanto a aparência das experiências humanas, sendo diante disso, inevitável essa dialética entre palavra e imagem. Nessa perspectiva, Renato Cunha (2007, p. 63) assevera que: 


\begin{abstract}
A relação entre literatura e cinema não se esgota. As leituras críticas expandem a capacidade intertextual das duas linguagens, que não perdem a originalidade. Se o diálogo existe, resiste e persiste, desde o aparecimento do cinema, é porque ambas se beneficiam de suas ilusões, que nada mais são do que novas formas de se expressar.
\end{abstract}

Segundo essas constatações, buscamos fazer nesse artigo, uma leitura comparativa entre o romance Vidas secas de Graciliano Ramos (1938) e a narrativa audiovisual Abril despedaçado de Walter Salles (2001), inspirado livremente no livro homônimo do albanês Ismail Kadaré. As referidas obras estão situadas em regiões devastadas pela seca, no Nordeste brasileiro, cujas temáticas giram em torno das relações do homem com o meio ambiente e/ou com o meio social, a partir do contexto familiar. Em Vidas secas, foi evidenciado o cotidiano do clã de Fabiano e sinha Vitória, que vivem a migrar numa região agreste do Nordeste do Brasil, buscando alternativas para resistir à seca e ao processo de desumanização. Já em Abril despedaçado, a família Breves também vivendo numa região de seca, limita-se à rotina marcada por uma tradição, que reflete um antigo código de honra. Tal código precisa ser cumprido com a realização de uma vingança, transformando a existência num eterno ciclo de morte.

\title{
1 As despedaçadas vidas secas
}

As formas de resistência configuradas nas relações familiares e de gênero, no livro Vidas secas, de Graciliano Ramos (1938) e no filme Abril despedaçado, de Walter Salles (2001) nos permitiram fazer um entrelaçamento entre essas duas narrativas, ressaltando tanto os traços de aproximação quanto os distanciamentos verificados nas personagens das referidas obras. Observamos, sobretudo, as personagens femininas sinha Vitória do romance de Graciliano Ramos, a personagem da mãe e Clara, do filme de Walter Salles, na forma como atuaram, exercitaram poderes e realizaram rupturas, subvertendo a opressão e o silêncio. Ademais, assumiram identidades adversas àquelas, prevalecentes nos contextos das suas trajetórias, marcadas de forma incisiva pelo falocentrismo. A preeminência da seca, da fome e da morte, não impediu que elas desenvolvessem formas de sobrevivência. Movidas pela esperança, pelo sonho, pelo sentimento de liberdade ou pela religiosidade encontraram forças para prosseguir. Essas personagens ratificam o pensamento de Michelle Perrot (2008, p.166) sobre o percurso das mulheres na história:

Em todos esses casos, trata-se, sobretudo, das mulheres às voltas com a violência, a guerra, e com formas de dominação masculina, das quais também os homens são vítimas. Entretanto, isso não esgota as relações entre os homens e as mulheres, do mesmo modo que o status de vítima não resume o papel das mulheres na história, que sabem resistir, existir, construir seus poderes.

A formação dos núcleos familiares, em ambas as narrativas, é a mesma: o pai, a mãe e dois filhos. Não há nessas relações a predominância do afeto. No filme, o afeto ficou evidenciado, especialmente, na relação entre os dois irmãos Tonho e Pacu, de certo modo, de forma até extremada. Porém, o mesmo não ocorreu entre as personagens do pai e da mãe, ou na relação destes com os filhos. No romance, o afeto era dirigido principalmente à cadela Baleia. Havia também entre os dois meninos uma espécie de cumplicidade. Estavam sempre juntos a brincar. Fabiano, o pai, muito embora não conseguisse expressar afeto pelas palavras ou gestos, em suas reflexões conseguia evidenciar sentimentos e emoções em relação aos familiares. Esse traço da escassez de afeto reflete a tradição patriarcal, que 
delineava os paradigmas a serem seguidos por homens e mulheres. De acordo com Peter Stearns (2007, p.34):

A força do patriarcado caiu sobre as mulheres, mas obviamente afetou também definições de masculinidade. Os homens independentemente da personalidade de cada um, deveriam assumir os seus papéis de dominantes. Deviam evitar mimar as mulheres, especialmente em público.

Essa postura masculina de supressão da afetividade era, evidentemente, extensiva aos filhos. Em Vidas secas, além da precariedade nas relações familiares, a miséria foi acentuada pelo desequilíbrio climático e pela ingerência do Estado. Fabiano e a família viviam em total abandono. Nas andanças pela caatinga durante a seca, conviviam inclusive, com a escassez de alimentação. Comiam o que encontrassem: capim, animais silvestres e raízes. No filme deu-se relevância à secura dos afetos, não obstante, economicamente a família estivesse em decadência, eles viviam nas próprias terras e não chegavam a passar fome. A fome existente era a fome de vingança. Fato este, demonstrado na metáfora construída pela personagem Pacu, quando aludiu a Riacho das Almas, o lugar onde vivia: “- O riacho secou, só ficaram as almas" (ABRIL, 2001). Entendemos que a secura do riacho à qual o menino se referia, remete também à agrura das pessoas que ali viviam. Conquanto, o tratamento dado à seca seja diferente, esta constitui aspecto comum às duas narrativas. Tanto o livro quanto o filme focalizam a seca, porém em planos distintos. Enquanto na narrativa literária destaca-se a paisagem do sertão em seus elementos climáticos e geográficos, na narrativa audiovisual o foco está sobre as pessoas.

No que se refere às presenças infantis nas duas obras, as crianças tanto em Vidas secas (1938), como em Abril despedaçado (2001) enfrentam a mesma indiferença dos adultos. Nas duas narrativas, as personagens infantis não possuem nomes, suas identidades são negadas e, por conseguinte, são silenciadas, pois também não lhes permitem o discurso. Os familiares adultos não incentivam os meninos nas suas aprendizagens porque, normalmente, os seus valores são incompatíveis com a curiosidade infantil. Os infantes vivem ante a incompreensão dos pais, estes, sempre indisponíveis para mediar a incursão dos pequenos nos domínios do conhecimento. Ao mesmo tempo, mantêm comumente, uma postura agressiva e autoritária, fazendo-os ora insistirem por respostas, ora encolherem-se temerosos, conforme pontua Resende (1988, p.56):

A criança que se vê diante de agressões ao seu ser, ora sendo útil ao adulto, insatisfeita nas suas aspirações, atua, normalmente sem nome, solitária, sem outras crianças com quem poderia compartilhar a infância. A falta de nome se justifica como remetente da desumanização que o menino vive na infância, devido a imposições que o adulto lhe faz e as restrições que a vida em si lhe oferece.

O menino Pacu, da filmografia de Walter Salles é uma exceção. Tal personagem não silenciava facilmente. Recebeu seu nome de um estranho transeunte, que passara nas proximidades da fazenda onde vivia. Por vezes, o menino foi para o enfrentamento e desafiou o autoritarismo do pai. Mesmo obrigado a trabalhar desde cedo e impossibilitado de adentrar ao universo lúdico, possuía grande capacidade imaginativa, esta lhe facultava escapar da dura rotina e criar uma realidade paralela onde podia brincar. Mergulhava na imensidão do mar, habitado por uma sereia e outros seres fantásticos. Sua inspiração vinha de um livro com o qual foi presenteado pela artista mambembe, Clara. Já a sua identificação era com o irmão Tonho, único familiar disposto a dar-lhe atenção. Pacu era questionador e corajoso, tanto assim, que caminhou para a morte em lugar do irmão, como 
se caminhasse rumo a uma nova vida. Isso traduz o pensamento de Vânia Resende (1988, p. 238) quanto à relação da criança com o mundo imaginário e o real:

Em atos de liberdade, ele ultrapassa ou quebra a dureza, a solidez e a estratificação da realidade imediata, a familiar, e das pessoas em geral [...], lançando-se como as águas que escorrem esparramadas e incontroláveis, à conquista do sentido interior e profundo das mesmas águas e de si próprio. Agora, águas vastíssimas do mar.

Já os dois irmãos de Vidas secas são identificados como menino mais novo e menino mais velho. O primeiro possuía grande admiração pelo pai, o vaqueiro Fabiano, e pretendia ser igual a ele quando crescesse. Considerava o pai o homem mais forte do mundo "E precisava crescer, ficar tão grande como Fabiano, matar cabras a mão de pilão, trazer uma faca de ponta à cintura. Ia crescer, espichar-se numa cama de varas, fumar cigarros de palha, calçar sapatos de couro cru" (RAMOS, 2000, p. 52). O seu universo resumia-se ao convívio com o irmão mais velho, a cadela Baleia e os animais de criação da fazenda. Sua imaginação era limitada, não possuía grandes sonhos, desejava coisas simples, como capturar um periquito. Temia os adultos, pois era tratado, tal qual o irmão, sob gritos, cocorotes e puxões de orelhas.

O menino mais velho era mais inquieto e questionador, enfrentava o medo e se arriscava a fazer perguntas sobre o que não entendia. Embora quase nunca obtivesse resposta. Mas, quando as tinha, não se contentava com a precariedade destas. Desconfiava de que estivessem incompletas ou não fossem verdadeiras. Muitas vezes, se consolava com a cadela Baleia. Suas curiosidades nem sempre se relacionavam com o cotidiano vivido, queria saber, por exemplo, sobre o inferno e sobre a movimentação dos astros: "Ao escurecer a serra misturava-se com o céu e as estrelas andavam em cima dela. Como era possível haver estrelas na terra? [...] O inferno devia estar cheio de jararacas e suçuaranas, e as pessoas que moravam lá recebiam cocorotes, puxões de orelhas e pancadas com bainha de faca" (RAMOS, 2000, p. 61). Contudo, considerava boa a vida que conhecia na fazenda, gozava de certa liberdade para brincar, podia se enlamear à vontade no barreiro com o irmão mais novo, de quem conhecia todos os medos. Por vezes, as traquinagens do menor eram para ele motivo de muito riso. Apesar da sua inocência, não se esquecia dos suplícios enfrentados durante a seca com a família, e da severidade dos pais. Conforme se observa no fragmento a seguir:

\footnotetext{
Nem sempre as relações entre as criaturas haviam sido amáveis. Antigamente os homens tinham fugido à toa, cansados e famintos. Sinha Vitória, com o filho mais novo escanchado no quarto, equilibrava o baú de folha na cabeça; Fabiano levava no ombro a espingarda de pederneira; Baleia mostrava as costelas através do pêlo escasso. Ele, o menino mais velho, caíra no chão que lhe torrara os pés. Escurecera de repente, os xiquexiques e os mandacarus haviam desaparecidos. Mal sentia as pancadas que Fabiano lhe dava com a bainha da faca de ponta (RAMOS, 2000, p.59).
}

O menino do filme de Walter Salles não gostava da vida que levava sempre carregada de muito trabalho. Enquanto os meninos de Vidas secas não eram obrigados a trabalhar, nem eram proibidos de brincar. Estavam sempre inventando brincadeiras com o que a natureza dispunha para eles. Contudo, o garoto mais velho, não se satisfazia apenas com elas, demonstrava curiosidade em saber mais sobre o mundo ao seu redor, por vezes, inquiria a mãe, como comprova a passagem do capítulo que diz respeito ao menino mais velho: "Estivera metido no barreiro com o irmão, fazendo bichos de barro, lambuzando-se. 
Deixara o brinquedo e fora interrogar sinha Vitória" (RAMOS, 2000, p. 56). Assim, os meninos do romance de Graciliano Ramos preenchiam as horas de suas existências. Em alguns momentos eram movidos pelo impulso de descobrir e apropriar-se do mundo, em outros, o preenchimento das necessidades essenciais lhes bastavam. Enquanto Pacu da narrativa audiovisual de Walter Salles comparava a vida à imensidão do mar. Sendo assim, para ele, só mergulhando e conhecendo a profundeza do mar poderia ser feliz.

\section{A tríade feminina e as rupturas nas duas histórias}

Daqui em diante, focalizamos as três personagens femininas das referidas obras, analisando as formas como estas dissolvem os paradigmas criados pela cultura patriarcal. Destacamos do romance Vidas secas (1938) de Graciliano Ramos, a personagem sinha Vitória para confrontá-la com a mãe e a malabarista Clara, personagens da narrativa do filme Abril despedaçado (2001) de Walter Salles. A escolha dessas personagens atende ao percurso realizado até agora, cujo principal objetivo visou estabelecer comparações entre as supracitadas narrativas, e, mais especificamente, aqui, problematizar as relações de gênero e a representação feminina. Da mesma forma, buscamos constatar o modo como essas mulheres se relacionam entre si, permitindo alavancar outras possibilidades de leitura dessas representações. Considerando-as enquanto transgressoras, que em seus respectivos lócus realizam intervenções nas regras impostas pelo masculino. Nelly Richard (2002, p. 165-167) ressalta a importância de se alterar as regras do discurso simbólico que prende a mulher a uma identidade predefinida:

\footnotetext{
Trata-se de um "eu" ou de um "nós" em processo, que move a identificação "mulher" em direção a múltiplos locais de redefinição contextual, em lugar de deixá-la amarrada a uma identidade predefinida. [...] Sabemos que não existe transformação do sistema de relações sociais sem uma alteração das regras do discurso simbólico, que ordena e formula o sentido. Da alteração dessas regras é que podem nascer novas figurações de pensamento, novos estilos de fala, novas constelações do imaginário.
}

Destarte, cada uma dessas personagens possui peculiaridades e formas de se conduzir, demonstradas a partir da elaboração dos seus discursos, é por meio destes, que subvertem as identidades nelas fixadas. A personagem da mãe se conduz pela emergência da morte dos filhos, cuja tragédia reflete o seu modo de dizer no silêncio. A imaginação e persistência na busca de uma vida menos miserável, marcam a trajetória de sinha Vitória que, movida pelo desejo, questiona a injustiça e a desigualdade social, enquanto Clara, mulher, artista, se movimenta com liberdade e escolhe o próprio caminho.

Tanto sinha Vitória de Vidas secas quanto a mãe de Abril despedaçado, mulheres do sertão nordestino, desempenhavam as funções domésticas de cuidar da casa, da alimentação da família entre outros afazeres. A última ainda agregava a estas funções o trabalho no cultivo da cana e na fabricação da rapadura. Entretanto, naquela conjuntura patriarcal, não era reconhecida como trabalhadora. Thayer (2001, p. 109) salienta sobre a invisibilidade do trabalho das mulheres no sertão:

No sertão, as vidas das mulheres eram divididas entre a casa e a roça. Em casa seu domínio fundamental, elas eram responsáveis pelas múltiplas tarefas envolvidas na reprodução social - cuidar das crianças, fazer faxina, lavar roupa e cozinhar, além de puxar água e criar animais para complementar a alimentação e a renda da família. Além disso, elas trabalhavam no cultivo de subsistência da família, junto com homens e com crianças com mais de sete anos. Mas tanto o 
trabalho doméstico, percebido como a ordem natural das coisas, quanto o trabalho na roça, visto como domínio masculino por causa do valor de troca produzido, ficavam invisíveis, sem reconhecimento social. Dado o papel do gênero na divisão do trabalho, as mulheres não eram reconhecidas como trabalhadoras, apesar da natureza indispensável de sua atividade na sobrevivência da família.

A mãe de Abril despedaçado não fugia a essa realidade. O trabalho realizado por ela na agricultura, e, na produção do produto responsável pela renda da família era totalmente invisível. A referida personagem não tinha acesso às finanças nem interferia nas decisões do marido.

$\mathrm{Na}$ área dos sentimentos, apesar de comportar-se com certa frieza em relação aos filhos, demonstrava na religiosidade o amor silenciado e dedicado a eles. Em suas preces, estes constituíam a preocupação central. Por vezes, era áspera com o filho mais novo, principalmente, no que se referia ao apego do menino ao livro recebido de Clara, artista circense. A mãe ralhava com ele e dizia: “- Tu não larga mais isso não, menino? Oxe! Não tá vendo que esse negócio aí faz mal pras vistas?” (ABRIL, 2001). Não consentia ao pequeno a singular oportunidade de atravessar a ponte entre o real e o fantástico, impedindo ao garoto o mergulho no mundo do devaneio, onde se encontrava com a sereia e outros seres encantados.

Em muitas ocasiões, a mãe deixava transparecer, de certo modo, a adesão às exigências feitas pelo marido aos filhos. O patriarca decidia sozinho sobre a vida e a morte dos meninos. Contudo, em outros momentos, mesmo timidamente, a mulher evidenciava posicionamento contrário às normas estabelecidas por ele. Como, por exemplo, ao romper o silêncio diante do marido e declarar apoio a Tonho, quando este fugira em companhia do pessoal do circo. Ele era o filho do meio, agora na condição de filho mais velho, estava marcado para morrer. Nesse sentido, a mãe desejava que o rapaz não retornasse e assim, não se cumprisse a sentença de morte em nome da honra da família. Ao ser repreendida pelo senhor Breves chegou a afirmar: "Qualquer forma de vida é melhor que a morte" (ABRIL, 2001). Não obstante, o silêncio predominasse durante todo o filme sobre o seu discurso, a personagem da mãe apresentava altivez em sua postura corporal. $\mathrm{O}$ olhar falava mais que as palavras, contrastando com a sujeição à que estava submetida. Revelava então, outro discurso pelo corpo. Judith Butler (2008, p. 187) discute a sujeição do corpo num contexto de dominação, que impede a produção do sujeito falante:

O corpo está sempre sitiado, sofrendo a destruição pelos próprios termos da história. E a história é a criação de valores e significados por uma prática significante que exige a sujeição do corpo. Essa destruição corporal é necessária para produzir o sujeito falante e suas significações. Trata-se de um corpo descrito pela linguagem da superfície e da força, enfraquecido por um "drama único" de dominação, inscrição e criação.

Ainda que, vivendo sob a dominação do masculino, tal postura altiva da mãe denunciava a sua incompatibilidade para com a morte prematura e sem sentido dos filhos. A personagem dizia com o corpo o que não expressava com o discurso verbal. No final da película, a mulher descentralizou o poder do homem, o qual após o assassinato prematuro do filho mais novo exigia que o filho do meio cobrasse o sangue de Pacu. O rapaz negouse a obedecê-lo e foi ameaçado de morte pelo próprio pai. Ao impedi-lo de atirar em Tonho, a mãe deu um basta àquela conjuntura baseada no ódio e na vingança, convertendo mais uma vez, o silêncio em discurso. 
Por seu lado, sinha Vitória, personagem feminina de Vidas secas, destacava-se pela competência discursiva em seu cotidiano. Era uma mulher muito faladora, esbravejava as suas insatisfações e não perdia de vista os seus sonhos. Vivendo a realidade da seca, não se sentia fadada àquele determinismo social. Na relação com os filhos demonstrava impaciência, principalmente, quando estes perguntavam sobre coisas que ela não dava conta de responder. Nessas horas, para se livrar da insistência dos garotos, aplicava-lhes doloridos cocorotes e/ou puxões de orelhas. Em outros momentos, comportava-se, ao seu modo, como uma mãe protetora. Fato este, evidenciado na passagem em que Baleia, a cadela de estimação da família, companheira de tantas andanças, adoeceu e precisou ser sacrificada por seu marido. Sinha Vitória tentou impedir que as crianças ouvissem o barulho do tiro ceifando a vida de Baleia. Buscou então, minimizar o sofrimento dos pequenos: "Sinha Vitória levou-os para a cama de varas, deitou-os e esforçou-se por taparlhes os ouvidos: prendeu a cabeça do mais velho entre as coxas e espalmou as mãos nas orelhas do segundo" (RAMOS, 2000, p. 86).

$\mathrm{Na}$ relação com o marido desfrutava de grande autoridade, pois não temia em interferir e questionar sobre as economias e os gastos da família. De certo modo, o poder exercido por sinha Vitória sobre Fabiano era totalmente impróprio ao contexto falocêntrico em que vivia. Esse poder é verificado em vários capítulos do livro, mas aqui utilizamos o oitavo, denominado "Festa", para exemplificá-lo, o qual narra o episódio em que a família deslocou-se da fazenda até a cidade para a festa de Natal. Relativo ao poder exercido pelas mulheres, Sandra Sacramento (2006, p. 570) denomina de contra poder o poder feminino no ambiente familiar.

Paradoxalmente, o contra poder exercido pela mulher no espaço doméstico, restrito, foi aquele que lhe entreabriu o espaço público, por meio da filantropia religiosa. Então, dialeticamente, o privado faz parte do público e o religioso também do secular. Dessa forma, justifica-se o "slogan" feminista de que "o privado é público".

Sendo assim, era através da sua atuação no espaço privado que sinha Vitória interferia no público. Na citada ocasião ela havia tratado de todos os preparativos para esse dia. Encomendara a Fabiano que comprasse tecidos e mandasse sinha Terta fazer roupas novas para que usassem no Natal. Após enfrentarem uma longa caminhada debaixo de forte sol, chegaram à cidade para participar da novena, e, à procura de diversão para as crianças. Fabiano sentia-se impelido a jogar apostado, no entanto, precisava do consentimento da mulher, pois a sua experiência com o jogo, normalmente, não era bem sucedida. Da última vez, o vaqueiro se envolvera numa aposta com um soldado e deu-se mal. Perdeu dinheiro, apanhou e ainda passou uma noite na cadeia. Mesmo assim, era tentado a entrar no jogo, sob o pretexto de ganhar dinheiro suficiente para comprar a cama de couro cru, tão desejada por sinha Vitória. Fabiano inquietava-se buscando uma assertiva da mulher por meio do olhar, conforme se constata no fragmento a seguir:

Convidou a mulher e os filhos para os cavalinhos, arrumou-os, distraiu-se um pouco vendo-os rodar. Em seguida encaminhou-os às barracas de jogo. Coçou-se puxou o lenço, desatou-o, contou o dinheiro, com a tentação de arriscá-lo no bozó. Se fosse feliz, poderia comprar a cama de couro cru, o sonho de sinha Vitória. Foi beber cachaça numa tolda, voltou, pôs-se a rondar indeciso, pedindo com os olhos a opinião da mulher. Sinha Vitória fez um gesto de reprovação, e Fabiano retirou-se, lembrando-se do jogo que tivera em casa de seu Inácio com o soldado amarelo. Fora roubado, com certeza fora roubado (RAMOS, 2000, p.77). 
Confirma-se, desse modo, o prestígio desfrutado por sinha Vitória junto ao marido. Fabiano dispensava grande admiração à mulher, considerava-a muito inteligente, por isso, a opinião dela era de extraordinária importância antes de qualquer decisão que o vaqueiro pudesse vir a tomar. Nisso, sinha Vitória diferenciava-se assaz da personagem da mãe, do filme Abril despedaçado, que a princípio, estava submetida ao domínio do marido e não questionava as suas determinações. Vivia acomodada em sua solidão. Ao invés disso, sinha Vitória tinha o espírito irrequieto, não se amoldava à miséria da seca, nem se importava em caminhar longas distâncias em busca de um lugar melhor para viver com a família. Essas duas personagens também divergem em outros aspectos, como, por exemplo, no modo de se vestirem.

Enquanto a mãe do filme vivia eternamente enlutada, despojada de qualquer vaidade, sinha Vitória era vaidosa e preocupava-se com a aparência. À semelhança da personagem Clara do filme Abril despedaçado, que também usava roupas rendadas e alegres. Sinha Vitória gostava de roupas coloridas, pedia ao marido para comprar-lhe cortes de tecidos com ramagens, como está bem demonstrado no fragmento do capítulo terceiro intitulado "Cadeia", quando Fabiano se encontrava preso e pensou na mulher: "lembrou-se de uma fazenda vista na última das lojas que visitara. Bonita, encorpada, larga, vermelha e com ramagens, exatamente o que sinha Vitória desejava" (RAMOS, 2000, p. 33). Os figurinos já denunciam o estado de espírito das três personagens. Enquanto a personagem da mãe de Abril despedaçado é a representação da tristeza e da morte, sinha Vitória e Clara encarnam a vida do início ao fim das respectivas narrativas, à revelia das demandas por estas enfrentadas. Munsterberg (1983, p. 49) analisa o vestuário enquanto moldura externa da personalidade:

O luto se manifesta na roupa preta, a alegria em roupas vistosas; [...] o estado de espírito passa para o ambiente; as impressões que configuram para nós a disposição emocional do próximo podem derivar dessa moldura externa da sua personalidade tanto quanto dos seus gestos e do seu rosto.

Não só em relação ao figurino, mas por outros traços, Clara, a artista circense do filme Abril despedaçado, também não se comportava de forma condizente com as normas ou convenções instituídas. A moça entra de modo triunfal na rotina familiar dos Breves. Surge como uma clareira na vida do jovem Tonho, indicando-lhe novos caminhos a seguir, uma vez que este, de certo modo, já se encontrava morto e condicionado ao jugo do poder patriarcal. A artista chegou a Bom Sossego, vilarejo localizado nos arredores da fazenda dos Breves, na companhia do padrinho Salustiano, com quem também mantinha uma relação amorosa. Muito embora, esse fato não seja confirmado com clareza na película, há cenas que trazem sutilezas desse relacionamento entre os dois. Clara era uma mulher do mundo, fascinava a todos por onde passava com a sua beleza exuberante. O modo de vida da moça indo de um lugar a outro, acompanhando o circo, a distanciava do cotidiano repetitivo e solitário das outras personagens femininas aqui analisadas. Além do talento no trapézio e no malabarismo com o fogo, possuía também, um grande poder de sedução. $\mathrm{O}$ comportamento transgressor de Clara evidencia a deficiência dos conceitos essencialistas sobre masculinidade e feminilidade. De tal modo, é relevante o pensamento de Badinter (2005, p. 53) ao dizer que "Não existe uma masculinidade universal, mas masculinidades múltiplas, assim como existem múltiplas feminilidades. As categorias binárias são perigosas, porque apagam a complexidade do real em benefício de esquemas simplistas e restritivos".

Clara representava uma feminilidade diversa dos padrões afirmados e assumidos por grande parte das mulheres do seu tempo. Movimentava-se com liberdade e 
desenvoltura, rompendo as fronteiras do espaço. A moça tinha consciência do seu corpo e do que poderia fazer com ele. Não permitia que outros inscrevessem nele padrões de comportamento, normalmente exigidos às mulheres. Assim, escrevia a sua história. Segundo Michelle Perrot (2008, p.41) "o corpo tem uma história, física, estética, política, ideal e material, da qual os historiadores foram tomando consciência progressivamente".

Ao contrário das demais personagens femininas analisadas, Clara era gentil com todos que dela se aproximavam. Deixava transparecer uma alegria contagiante e nenhuma amargura. Um exemplo disso foi o seu encontro com o menino Pacu, logo convertido em amizade, selada com um livro presenteado à criança pela moça. $\mathrm{O}$ livro permitiu ao garoto adentrar no mundo da fantasia, mudando assim para sempre a vida dele. Clara personificou a sereia na imaginação do menino. Tonho, o irmão mais velho de Pacu, apaixonou-se pela moça no primeiro olhar. Entre eles, não houve cobranças ou pactos de compromisso, conforme as exigências da tradição falocêntrica. Viveram intensamente os momentos em que puderam estar juntos. Conquanto Salustiano demonstrasse poder sobre Clara, ela não se submeteu a ele.

A religiosidade é outro aspecto presente em ambas as narrativas. A personagem da mãe de Abril despedaçado e sinha Vitória de Vidas secas se assemelhavam em suas devoções, que remetiam ao catolicismo popular, difundido no Nordeste. Confirmando assim, uma característica marcante da mulher sertaneja, de resignação e fé. Normalmente, influenciada pelo arquétipo da mãe de Cristo, a quem dedicavam muitas rezas e novenas. Quanto a esse aspecto da religiosidade, Badinter (1986, p.103) ressalta:

O culto de Maria não constitui apenas uma homenagem prestada à mãe, também marca que, se uma mulher causara a perda da humanidade (Eva), outra contribuiu para salvá-la (Maria). Com isso, devolvia à mulher um status honroso e trazia a prova de que aquela que fora rejeitada como nefasta e perigosa, podia tornar-se objeto de salvação e veneração.

Nesse sentido, ambas buscavam na fé ajuda para solucionar as demandas que estavam fora do alcance de suas forças. A mãe do filme Abril despedaçado mantinha um altar em um dos cômodos da casa e para lá se dirigia nos momentos de aflição. O altar era o lugar sagrado, onde a mãe chorava as suas dores e a saudade de Inácio, o filho morto. Também entoava cânticos próprios à ocasião. Pedia descanso para a alma do filho e proteção para os vivos. Já sinha Vitória carregava um rosário ao pescoço, do qual lançava mão nos momentos difíceis para conduzir as preleções, através das quais introduzia o diálogo com o divino. Por vezes, a lembrança da seca deixava sinha Vitória angustiada. Temia passar mais uma vez por aquela experiência. Todavia, ao mesmo tempo, temia também a chuva, por isso recorria à oração diante de qualquer dificuldade enfrentada. Um exemplo disso está na passagem do capítulo "Fuga", quando ela e a família decidiram fugir para uma cidade grande, que não sabiam ao certo onde se localizava. Sinha Vitória estava apreensiva, pois ciente da responsabilidade que tinha sobre aquela decisão da família, resolveu apelar para a sua fé. Afinal, estavam fugindo também das dívidas com o patrão: "A vida na fazenda se tornara difícil. Sinha Vitória benzia-se tremendo, manejava o rosário, mexia os beiços rezando rezas desesperadas" (RAMOS, 2000, p. 116). Tanto no romance quanto no filme, as mulheres são responsáveis por estabelecer a ligação entre o plano material e o espiritual, nos momentos decisivos. Conforme salienta Neitzel (2004, p. 104) sobre a importância das crenças populares para as pessoas que vivem no sertão. 
Num espaço como o sertão, eivado de superstições e crenças enraizadas na cultura popular, afastado do mundo urbano, mais próximo do universo medieval no qual o dualismo Deus/demônio faz parte do imaginário coletivo, a presença de rezadeiras, feiticeiras e bruxas é de grande valia.

Nesse aspecto, Clara é a única exceção entre as três. Em nenhuma cena do filme, a artista deixou transparecer a sua vinculação ao divino ou aludiu a alguma preferência religiosa, crença ou medo, parecia acreditar apenas na vida e no amor que passou a sentir por Tonho. Logo, rompeu com o padrinho e foi ao encontro do rapaz.

Diante disso, observa-se que cada uma dessas três personagens efetuou, ao seu turno, transgressões e rupturas, abalando estruturas e alterando o curso das suas histórias. Apesar de não possuírem consciência da posição ocupada por elas, enquanto mulheres, na conjuntura social, deslocaram os discursos logofonofalocêntricos, desconstruindo a hierarquia patriarcal. "Desconstruir a oposição é, primeiro, num determinado momento, derrubar a hierarquia" (DERRIDA, 1975, p. 54). Estes discursos, cujas bases se desenvolveram na Antiguidade Clássica, mais especificamente no pensamento platônico, foram responsáveis pela criação dos valores dicotômicos, que sedimentaram na cultura ocidental todas as ordens de dominação. A desconstrução alcançada por essas personagens assemelha-se ao que Derrida (1998, p. 23) propõe quanto ao entendimento desse termo:

\begin{abstract}
A desconstrução tem lugar, é um acontecimento que não espera a deliberação, a consciência ou a organização do sujeito, nem mesmo da modernidade. Isso se desconstrói. O isso não é aqui uma coisa impessoal, que se oporia a alguma subjetividade egológica. Está em desconstrução (Littré dizia: desconstruir-se... perder sua construção). E o "se" do desconstruir-se, que não é a reflexividade de um eu (ego) ou de uma consciência, carrega todo o enigma.
\end{abstract}

A desconstrução proposta por Derrida remete à desmontagem de todos esses valores logofonofalocêntricos, organizados a partir de oposições onde o segundo dos pares é sempre inferior ao primeiro, definindo o pensamento ocidental em nome de uma razão, que descartava as subjetividades, como forma de se atingir a verdade. Padronizando nos corpos comportamentos geradores de discriminações, exclusões e intolerâncias, predominantes ainda na contemporaneidade. Tais valores interferem nas relações entre os sujeitos, conforme têm sido apontados nos estudos de gênero atuais, cujo foco consiste em discutir o reconhecimento das múltiplas identidades. Quanto a isso, Carlos Magno Gomes (2008, p. 74) assegura a relação entre os estudos de gênero e a busca de espaço para essas novas identidades.

Buscando espaço para novas identidades, os estudos de gênero têm cada vez mais se firmado como uma estratégia de interpretação da identidade pósmoderna. Além disso, a desnaturalização do biológico e do natural produziu uma arrojada agenda feminista guiada pelo descentramento do caráter biológico do gênero e que passou a ser interpretado como uma construção cultural.

$\mathrm{Na}$ perspectiva de uma nova identidade, a personagem da mãe do filme Abril despedaçado, opera no silêncio a sua reação de inconformidade, trazida à tona no final da película, ante as exigências do marido, que, para manter uma tradição ancestral da família, oferecia a vida dos filhos em sacrifício, na disputa pela terra com um fazendeiro vizinho. Por sua vez, Sinha Vitória do romance Vidas secas, assume a liderança do seu clã diante da incapacidade enunciativa do marido. Mesmo imersa em uma conjuntura de tamanha miséria, era ouvida em todas as decisões da família e detinha sempre a palavra final, desconstruindo, nessa acepção, o modelo falocêntrico, onde o lugar de fala cabia ao 
homem. Já Clara, a artista circense, também personagem do filme Abril despedaçado, apresenta-se, desde o início de sua aparição, com um comportamento adverso aos costumes de seu tempo, quando a mulher era submetida ao silêncio e ao quase isolamento. Utilizando-se principalmente do seu corpo, enquanto forma de expressão e de linguagem, circulava no espaço público e ocupava as praças das cidades por onde passava. Lugares estes, marcadamente masculinos. Além disso, não admitia que outros tomassem decisões por ela, fazia as suas próprias escolhas e dirigia a sua vida. Todas essas três personagens interferiram sobremodo em suas realidades, como se antevissem e anunciassem o futuro das lutas das mulheres, disseminadas na segunda metade do século XX, provocando uma série de descentramentos em grande parte do mundo. Estes movimentos chegaram ao século XXI sob outros matizes, agregando em si, diversas bandeiras de luta. Linda Hutcheon (1991, p. 85) discute esses descentramentos como a busca do sujeito pela individualidade e autenticidade:

O local, o regional e o não totalizante são reafirmados à medida que o centro vai se tornando uma ficção - necessária, desejada, mas apesar disso uma ficção. A nova descentralização do sujeito e de sua busca no sentido da individualidade e da autenticidade teve importantes repercussões sobre tudo, desde nosso conceito de racionalidade até nossa visão de possibilidades de gênero.

Tal constatação sanciona que o ser humano pode produzir mecanismos de resistência e subversão, nas mais diversas conjunturas sociais, e do mesmo modo, comunicar-se a partir de diferentes formas de linguagem. Por meio dessas linguagens os sujeitos constroem significados, os quais estão relacionados com as convenções culturais, que são impostas, aceitas ou não por eles. Nas referidas personagens percebe-se o silêncio, a fala e a linguagem corporal, como mecanismos utilizados para provocar descentramentos.

Do mesmo modo, ocorre com o olhar subversivo do receptor sobre as narrativas de ficção, que podem ser produzidas em diferentes linguagens. Quer seja na linguagem verbal, tanto escrita quanto oral, quer seja na linguagem audiovisual. Na literatura, expressão artística, cuja matéria é a palavra transcrita ou recriada num universo ficcional pela imaginação tanto do autor quanto do leitor, a construção de uma imagem depende das ideias que os sujeitos possuem da coisa imaginada. Como numa espécie de jogo, ela vai sendo montada mentalmente, por meio de pistas e descrições fornecidas na narrativa, acerca das personagens, do cenário, etc. Talvez, o maior encantamento da literatura jaz na possibilidade que cada um possui para construir imagens e atribuir significados.

De outra forma, o cinema que também consiste numa manifestação artística, agrega uma multiplicidade de linguagens verbais e não verbais apresentadas simultaneamente. Há em relação ao espectador de um filme, a necessidade de aguçar não apenas a imaginação, mas, também, outros sentidos, que contribuem para a construção de significados, como a audição e a visão, pois no filme a imagem já está dada, o espectador estabelece o significado sobre ela a partir do olhar. Essa capacidade imaginativa e esse olhar atuam na constituição de novos sentidos traduzindo-se em fissuras que minam a realidade vivida e fragmentam preconceitos sedimentados, ao tempo que fazem insurgir outras formas de acordos sociais. No romance Vidas secas (1938), a imagem é configurada pelo caráter descritivo da obra, que permite ao leitor interpretar e compor imaginativamente os significados. Já no filme Abril despedaçado (2001), a imagem se converte em discurso não verbalizado, cujos sentidos são concebidos pela imaginação do receptor. 


\section{Considerações finais}

A crítica feminista evidencia, portanto, a convergência existente entre as teorias aqui apresentadas e os estudos de gênero, estabelecendo campos interdisciplinares de pesquisa que se imbricam exigindo a necessidade de uma visão anti-essencialista. Da mesma forma, permitem um olhar desconfiado sobre os discursos construídos, as identidades e os fundacionismos há muito instituídos como verdades pelo logus ocidental. Esse olhar desconfiado põe em xeque as estruturas que definem, naturalizam e balizam os sujeitos, mas, são incapazes de dar conta das heterogeneidades. Ademais, a análise desse corpus corrobora para uma reflexão acerca de questões concernentes às mulheres e aos homens que, em nome de convenções coercitivas disseminaram concepções sobre a feminilidade e a masculinidade. Tais pontos de vista reproduziram formas de dominação, normatizaram comportamentos, de modo a demarcar nos corpos os seus destinos. Igualmente, provocaram o alijamento de uma variedade de gêneros, cujas particularidades não se emolduravam nesses paradigmas.

Considera-se então, que tanto o livro Vidas secas de Graciliano Ramos quanto o filme Abril despedaçado (2001) de Walter Salles possibilitam discutir demandas cujo objetivo seja romper com o espectro hierárquico entre os sujeitos. Destarte, ambas as ficções compõem excelente material para se observar demandas relativas aos valores hegemônicos, os quais confirmam aspectos da violência física ou simbólica que incidem sobre as mulheres e demais minorias, percebidos nas diferentes formas de controle. Valores estes, denunciados nos diversos contextos sociais. Atinente a isso Badinter (2005, p. 50) defende a necessidade de se combater a dominação masculina tanto quanto outras formas de supremacia:

\footnotetext{
Essa divisão do mundo, essa cosmogonia baseada no gênero, é mantida em funcionamento e regulada por formas de violência: atos múltiplos e variados de violência que, das formas domésticas da violência masculina aos estupros de guerra, passando pelos atos de violência no trabalho, tendem a preservar os poderes que os homens se atribuem, coletiva e individualmente, à custa das mulheres. Portanto é preciso lutar contra a dominação masculina, do mesmo modo como se combatem o racismo e o fascismo.
}

Essas dicotomias instituídas entre o espaço público e o privado culminaram por atribuir aos homens o domínio do discurso, da cultura e da política, enquanto as mulheres foram vinculadas ao silêncio, à natureza, às práticas cotidianas e domésticas. A forma como esses sujeitos têm sido representados exigirá muitos debates, além disso, demandará muito tempo para ser desmistificada, de modo a transformar o panorama histórico e/ou cultural em espaços de equidade.

A análise comparativa, realizada nesse artigo, possibilitou a percepção de diálogos e analogias entre essas duas obras e o contexto histórico. Sobremodo, no que se refere às contingências de vida das mulheres, bem como, às fissuras abertas por elas, comprovando, portanto, as instabilidades do poder masculino. Ao mesmo tempo, permitiu perceber as dissonâncias e paradoxos apresentados a partir de uma variedade de elementos, da qual se apropria o olhar contemporâneo, na busca de ulteriores sentidos para esses textos.

Diante disso, pode-se observar a desestabilização de identidades fixas tanto nas personagens femininas, quanto nas masculinas. Tal entendimento verifica-se a partir dos comportamentos de subversão, que resultam na pulverização dos conceitos tradicionais acerca das relações entre os sujeitos. As respectivas narrativas descortinam diante do leitor/receptor uma diversidade de formas de viver, impulsionando, desse modo, as 
personagens a seguirem em frente. As configurações apresentadas no livro e no filme refletem em suas demandas existenciais locais, do Nordeste brasileiro, a tradição logofonofalocêntrica. Todavia, esses mesmos valores androcêntricos geraram a produção de estratégias de resistência por parte daqueles que viviam na condição de subjugados. Nesse contexto, a literatura e o cinema se revelam como importantes mecanismos para a formulação de novos paradigmas, capazes de possibilitar outro imaginário do feminino e do masculino, que considerem as especificidades de homens e mulheres em suas respectivas práticas sociais e suas múltiplas representações. Conforme podem atestar as supracitadas obras, aqui analisadas numa perspectiva comparatista.

\section{REFERÊNCIAS}

ABRIL despedaçado. Direção Walter Salles,; roteiro de Walter Salles, Sérgio Machado e Karim Aïnouz; produção: Monica Lima e Ibiraba Pimenta Junior. São Paulo: Distribuição: Imagem Filmes, 2001. 1 videocassete ou DVD (95min.): VHS, NTSC, son. Color. Legendado ou dublado.

BADINTER, Elisabeth. Um é o outro: relações entre homens e mulheres. Tradução de Carlota Gomes. Rio de Janeiro: Nova Fronteira, 1986.

BADINTER, Elisabeth. Rumo equivocado: o feminismo e alguns destinos. Tradução de Vera Ribeiro. Rio de Janeiro: Civilização brasileira, 2005.

BUTLER, Judith. Problemas de gênero: feminismo e subversão da identidade. Tradução de Renato Aguiar. Rio de Janeiro: Civilização Brasileira, 2008.

COUTINHO, Everaldo. A imagem autônoma. São Paulo: Ed. Perspectiva, 1996.

CUNHA, Renato. Cinematizações: idéias sobre literatura e cinema. Brasília: Círculo de Brasília, 2007.

DERRIDA, Jacques. Posições. Tradução Maria Margarida C.C. Barahona. Lisboa: Plátano, 1975.

DERRIDA, Jacques. Carta a um amigo japonês. Tradução Érica Lima. In: OTTONI, Paulo (Org.). Tradução: a prática da diferença. Campinas: Ed. da UNICAMP, 1998.

GOMES, Carlos Magno. Identidade pós-moderna na narrativa de Lya Luft. In: GOMES, Carlos Magno; ENNES, Marcelo Alario (Org.). Identidades: teoria e prática. São Cristóvão: Editora UFS, 2008.

GOMES, Carlos Magno; ENNES, Marcelo Alario (Org.). Identidades: teoria e prática. São Cristóvão: Editora UFS, 2008.

HUTCHEON, Linda. Poética do pós-modernismo: história, teoria, ficção. Rio de Janeiro: Imago, 1991.

JOHNSON, Randal. Literatura e Cinema, diálogo e recriação: o caso de Vidas secas In: PELLEGRINI, Tânia. et al. Literatura, cinema e televisão. São Paulo: Ed. SENAC, 2003.

MUNSTERBERG, Hugo. As emoções. In: XAVIER, Ismail (Org.). A experiência do cinema. Rio de Janeiro: Edições Graal, 1983.

NEITZEL, Adair de Aguiar. Mulheres rosianas: percursos pelo grande sertão: veredas. Florianópolis: UNIVALE Editora, 2004. 
OTTONI, Paulo (Org.). Tradução: a prática da diferença. Campinas: Ed. da UNICAMP, 1998.

PELLEGRINI, Tânia. et al. Literatura, cinema e televisão. São Paulo: Ed. SENAC, 2003.

PERROT, Michelle. Minha história das mulheres. Tradução de Angela Corrêa. São Paulo,

Contexto, 2008.

RAMOS, Graciliano. Vidas secas. Rio de Janeiro: Ed. Record, 2000.

RESENDE, Vânia Maria. O menino na literatura brasileira. São Paulo: Perspectiva, 1988.

RICHARD, Nelly. Intervenções críticas: arte, cultura, gênero e política. Belo Horizonte: Ed. UFMG, 2002.

SACRAMENTO, Sandra Maria Pereira do. Mulheres emparedadas e seus espaços de memória. Revista Estudos Feministas, Florianópolis, v. 14, n. 2, maio/set., 2006.

STEARNS, Peter N. História das relações de gênero. Tradução de Mirna Pinsky. São Paulo: Ed. Contexto, 2007.

THAYER, Millie. Feminismo transnacional: re-lendo Joan Scott no sertão. Revista Estudos Feministas, Florianópolis, v. 9, n. 1, jan./jun., 2001.

XAVIER, Ismail. (Org.). A experiência do cinema. Rio de Janeiro: Edições Graal, 1983. 